Harka Ödön

\title{
A gépesített hadviselés kérdésének szovjet megközelítése a két világháború között
}

2. rész

\section{The Soviet Approach of the Mechanised Warfare in the Period between the Two World Wars}

Part 2.

\begin{abstract}
Absztrakt
Isszerszon tábornok rámutatott arra, hogy a hadmüveletek jellegét az I. világháború -az arcvonalak kiszélesedése és a csapatok mélységi diszlokációja miatt-alapvetően változtatta meg. A tábornok a tartalék szerepét jelentösen átértékelte, álláspontja szerint a tartalékok elsődleges feladatává a hadmüveleti erökifejtés mélységben történö fenntartása vált. Víziója szerint a katonai erök lépcsőzötten megvalósuló küzdelembe vetése mind hadászati, mind pedig hadmüveleti szinten is szükségessé válik. Tevékenységének (is) köszönhetöen fokozatosan kialakult a mély hadmüvelet elmélete, amely szerint a célszerü hadmüveleti felépités a következö: első (légi) lépcső: a légierö és légideszantcsapatok bevetésével, a célja a hadmüveleti mélység bénitása; második (roham)lépcső: a csapásmérő hadsereg alkalmazásával, a célja a harcászati mélység áttörése; harmadik (sikerkifejlesztö) lépcső: célja gyorscsapatok bevetésével a hadmüveleti siker elérése (M. Szabó Miklós: Az európai hadügy fejlődése a XIX-XX. században. Elöadás. 140-142. kép.).
\end{abstract}

Kulcsszavak: Isszerszon, mély hadmüvelet, hadmüveleti lépcsö, áttörés, gépesitett hadviselés

Nemzeti Közszolgálati Egyetem, Hadtudományi Doktori Iskola, doktorandusz - University of Public Service, Doctoral School of Military Sciences, PhD student, e-mail: odon.harka@eulerhermes.com 


\begin{abstract}
General Isserson pointed out that as a consequence of the First World War, the nature of military operations - due to the wider front lines and deeper dislocation of the units - changed basically. Isserson revalued the role of reserve troops, in his view their primary task is to maintain in depth the operational efforts. He assumed that the gradual application of the military forces will be needed in the future both on operational and tactical level. Due to his assumptions, the theory of the deep operations was formed gradually, as follows. In the first (air) echelon, the air force and airborne troops are to paralyse the operational depth. In the second (assault) echelon, the striking army's goal is to break through the tactical depth. The goal of the third (success development) echelon is to achieve operational success by using rapid units.
\end{abstract}

Keywords: Isserson, deep operation, operational echelon, break-through, mechanised warfare

\title{
1. Georgij Szamojlovics Isszerszon
}

A két világháború közötti szovjet katonai gondolkodók körében említést kell tenni Georgij Szamojlovics Isszerszon ${ }^{2}$ tábornokról is, aki a Tuhacsevszkij tábornok által kidolgozott úgynevezett „mély hadmüvelet” elméletét fejlesztette tovább. Az 1933-ban megjelent, $A$ mély hadmüvelet alapjai címü munkájában a szerző a hadászat kérdésén belül is az áttöréssel és annak kiszélesítésével foglalkozott, ${ }^{3}$ amelynek föbb tézisei az alábbiakban foglalhatóak össze:

Isszerszon tábornok a hadműveleti tervezés „művészete” kapcsán általánosságban is rámutatott arra, hogy a tömeghadseregek korában a fegyveres harc eszközei rendkívüli mértékben különböznek egymástól, a harcrendbe történő szétbontakozás nagyon bonyolult és jelentős problémákat okoz az utánpótlás (hadtáp) megszervezésében. Mindemellett, az egyes hadműveletek megszervezése és irányítása további megoldandó kérdéseket vet fel, amelyeket elméleti síkon is szükséges megérteni és az adekvát válaszokat kidolgozni. A szerző művében a hadműveleti tervezés és végrehajtás fő feladataként a megsemmisítő mély hadművelet elmélete alapjainak kidolgozását határozta meg. ${ }^{4}$

A hadmüveletek jellegét az I. világháború és az akkor megjelent haditechnikai eszközök (harckocsik és repülögépek) alapvetően változtatták meg, a fejlődés két irányban idézett elő változásokat: egyrészt az arcvonalak kiszélesedésében, másrészt

\footnotetext{
Isszerszon, Georgij Szamojlovics (1898-1976). Részt vett a polgárháborúban, 1924-ben elvégezte a Katonai Akadémiát, majd különböző parancsnoki és törzsbeosztásokban szolgált. 1936-ban a Vezérkari Akadémia Hadműveleti múvészet tanszékének vezető professzora lett. Innen ment nyugdijba 1955-ben. Fontosabb írásai: A hadmüveleti müvészet fejlődése (1932), A mély hadmüvelet alapjai (1933), A hadmüvelet vezetésének alapjai (1938), A küzdelem új formái (1940). Holecz József: A Geraszimov-doktrína - Egy másik megvilágításban. Felderítő Szemle, 16. (2017), 3-4. 5-28. 22.; A harckocsi csapatok fejlődése. G-portál, 2007.

Resperger István: A gépesített hadviselés elmélete és megvalósítása, a Blitzkrieg. AETAS, 22. (2007), 4. 34

4 Ölvedi Ignác (szerk.): Szemelvények a szovjet katonai teoretikusok és katonai írók müveiböl 1917-1940. Budapest, Zrínyi Miklós Katonai Akadémia Hadmüvészet Története Tanszék, 1969. 55-56.
} 
az egységek mélységben megvalósuló tagozódásában. Isszerszon tábornok felismerte a változásokat, álláspontja szerint a jövő küzdelmeiben az egyes arcvonalak további szélesedése várható, emellett a mozgósítás tempójának növekedése a hadműveletek sürüségének növekedését is eredményezni fogja. ${ }^{5}$

A gépesítettség növekvő fokára tekintettel, a hadműveleti manőverezés lehetőségei bővülnek, a veszélyeztetett szárnyak gyorsan meghosszabbíthatóak, így a jövő parancsnokainak és hadműveleti tervezőinek tényként kell elfogadniuk azt, hogy a megkerülö manőverek helyét a frontális támadások veszik át, amelyeket ugyanolyan határozottan kell végrehajtani, mint a megkerülő csapatmozgásokat, és amelyeknek ki kell terjedniük a korszerű védelmi lépcsők teljes mélységére. Georgij Isszerszon az 1930-as évek elején felállított teóriájában az első védőőv mélységét (hadosztályra vonatkoztatva) 6-8 kilométerben határozta meg, a második védőöv (hadosztálytartalék) az első védelmi vonaltól mintegy 8-10 kilométerre helyezkedik el. A hadseregtartalék körülbelül 20-25 kilométer távolságban diszlokál, ezen egységek képezik a harmadik védőövet. A hadseregtartalék mögött további 25-40 kilométer távolságra helyezkednek el az ellátóegységek, amelyek képesek fogadni az új tartalékokat. A korszerü hadműveleti mélység kiterjedése ily módon elérheti a 60-100 kilométert, amelyet a jövő támadó hadmúveletei le kell hogy küzdjenek. ${ }^{6}$

A nagy mélységben folyó küzdelmek központi kérdése annak tisztázása (felderítése), hogy a szemben álló erők milyen mélységben tagozódnak, és milyen mértékben képesek az ellenállás kifejtésére. A szerző az I. világháború eseményeit elemezve leszögezte, hogy az elöretöréssel párhuzamosan nő az ellenállás ereje, amely a támadás végcéljához közeledve éri el a kulminációs pontját, így a legnagyobb erőkifejtéssel a tervezőknek az adott hadművelet befejező időszakában kell számolniuk. A korszerü ellenállási vonalak mélyen lépcsőzöttek, egyetlen csapással nem zúzhatóak szét, emiatt a hadműveleti felépítésnek is nagy mélységben kell megvalósulnia oly módon, hogy a támadási végcél megközelítése függvényében fokozható legyen az erőkifejtés. A támadás erőcsoportosítása azonban nem korlátozódhat az erők részenkénti bevetésére, annak egymás után következve, folyamatosan kell megtörténnie. A szükséges erö- és haditechnika mennyiségi meghatározása nem csupán az arcvonal szélességének függvénye, a tervezés során a művelet mélysége is tekintetbe veendő.?

Míg Clausewitz ${ }^{8}$ tábornok a hadászati tartalékok képzését feleslegesnek tartotta, von Schlieffen tábornok ezt már realitásként kezelte, ő azonban a tartalékok szerepét az arcvonalak meghosszabbításában látta. Isszerszon tábornok a művében a tartalék szerepét jelentősen átértékelte, álláspontja szerint ezek elsődleges feladatává a hadműveleti erőkifejtés mélységben történő fenntartása vált: a hadműveleti és hadászati tartalékok kérdésköre az 1930-as évekre már a hadműveleti lépcső körébe került át, amely mögött, a mélységben már kirajzolódtak a hadászati lépcsők körvonalai. ${ }^{9}$

\footnotetext{
Ölvedi (1969) i. m. 56.

Ölvedi (1969) i. m. 58.

Ölvedi (1969) i. m. 59.

Clausewitz, Carl Philipp Gottlieb von (1780. 06. 01. - 1831. 11. 16.) porosz tábornok, hadtörténész, valamint katonai teoretikus. Legismertebb munkája a hadtudomány egyik alapmüvének számító többkötetes könyve, amelynek címe: A háborúról. Carl von Clausewitz. Wikipédia.

Ölvedi (1969) i. m. 60.
} 


\section{A hadműveletek mélységi tagozódása}

Az 1930-as évek elejére nyilvánvalóvá vált a tábornok számára az, hogy a jövő fegyveres konfliktusaiban a mozgósítás fokozatos jelleget fog ölteni, a lépcsős mozgósítás pedig a hadászati erőkifejtés lépcsőzött megvalósítását fogja eredményezni. A katonai erők lépcsőzötten megvalósuló küzdelembe vetése mind hadászati, mind pedig hadmüveleti szinten is szükségessé válik, tekintettel arra is, hogy az egyes hadseregek rendelkezésére álló haditechnikai eszközök hatótávolságában és lőtávolságában jelentős fejlődés mutatkozik. Míg a napóleoni háborúk során a főerők közvetlenül a harcmező előtt bontakoztak szét, a 19. század második felében egyre inkább előtérbe került a menetből történő szétbontakozásra és a találkozóharc-tevékenység folytatására való törekvés, köszönhetően a tüzérség hatótávolságának megnövekedésére. A jövő csatái már nagy távolságokból fognak megkezdődni, s a harcászati távolságok (például menetbiztosítás távolsága) is megnőnek. ${ }^{10}$

Hadműveleti vonatkozásban azonban a távolság más dimenziókat képvisel, ezen esetben ugyanis amennyiben a hadseregparancsnok vezetni kívánja a csapatait a mély hadművelet során, úgy az ellenséges hadműveleti csapást megelőzően, a szétbontakozás kezdetére meg kell hoznia elhatározását. Ehhez azonban a föerőktől 1-2 napi menettávolságra elhelyezkedő csoportosítással kell rendelkeznie. A jövő küzdelmei során Isszerszon tábornok szerint kísérteni fog a napóleoni múlt, ugyanis újra megjelenik majd a hadseregelővéd kategóriája, a találkozóharc azonban a harcászat szintjéről átkerül hadászati szintre, az elővéd előretolt alegységei által megkezdett találkozóharc hadműveleti szinten találkozóütközetbe fordul át, amikor is az elővéd a hadseregelővéd feladatát látja majd el. A támadás hadműveleti felépítése ennek okán mélylépcsős formát fog ölteni.1"

A fenti okfejtés a gyakorlatban a következő módon valósulhat meg:

- a légierő a háború első óráiban tömeges bevetésekkel távolsági csapásokat mér az ellenséges állásokra, illetve infrastruktúrákra;

- a légierő műveleteit közvetlenül követően a szárazföldi haderőnem gyorsan mozgó egységei (gépesített lovas-, gyalogos- és harckocsiegységek) képezik az első elővédlépcsőt, feladatuk az ellenséges csoportosítás megbontása, a szétbontakozásuk megakadályozása;

- az elővéd küzdelmei során az összfegyvernemi gyalogos-magasabbegységek föerőként fokozatosan (nem egyszerre) megérkeznek a hadszíntérre, és felveszik a harcot. A föerők is lépcsőzötten avatkoznak be a küzdelembe, létrehozva ezzel a második és harmadik hadműveleti lépcsőt;

- az első hadászati lépcső mozgásba lendülésével párhuzamosan, az ország mélységében már körvonalazódnia kell a mozgósitás következtében a második hadászati lépcsőnek, így, a fentiek alapján, az egész hadászati lépcső mintegy 250-300 kilométer mélységet tesz ki.12

\footnotetext{
Ölvedi (1969) i. m. 61.

Ölvedi (1969) i. m. 61-62.

Ölvedi (1969) i. m. 62.
} 
Mindebből levonható az a következtetés, hogy míg a vonalhadászat korában az ütközet elkülönült a hadművelettől, addig a mélyhadászat időszakában a hadművelet és az ütközet szervesen összekapcsolódik, közöttük időben és térben elmosódnak a határok. A jövő háborúinak ütközetei a növekvő hadműveleti erőkifejtések folyamatában az arcvonal szélességében alakulnak ki és a mélységében fejeződnek be. A szemben álló haderők a rendelkezésükre álló forrásokat fokozatosan vetik be, a végső siker azé a félé lesz majd, amelyik mélyebb hadműveleti felépítéssel rendelkezik. ${ }^{13}$

\section{A mélységi áttörés jelentősége, a hadmüveleti felépítés}

A szerző szerint az arcvonalakat döntő hadműveletekben célszerủ majd áttörni, amit a teljes ellenséges mélységre szükséges kifejleszteni, és el kell érni a végső célt, azaz az arcvonal teljes összeomlását. A harckocsik (gyorscsapatok), a messze hordó tüzérség és a légierő alkalmazása az áttörés harcászati problémáját megoldják, a hadműveleti tevékenységnek azonban csak egyik elemét jelentik. A jövő háborúi során az ellenség megsemmisítése csak azon esetben végrehajtható, amennyiben a harcászati áttöréshez szükséges erőkön kívül az adott vezetö rendelkezésére állnak a harcászati áttörés mélységbe való kifejlesztéséhez szükséges erők is. A győzelem azé a félé lesz, amelyik mélyebb és erősebb lépcsőkkel rendelkezik. ${ }^{14}$

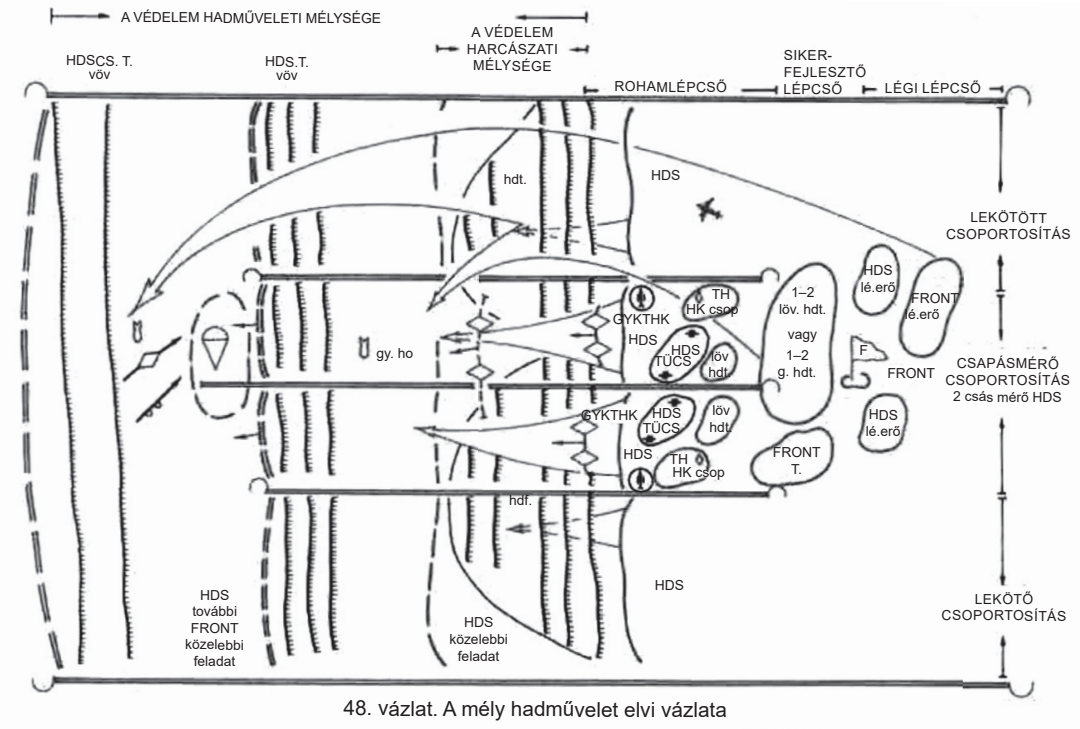

1. ábra: A mély hadmüvelet elvi vázlata

Forrás: M. Szabó Miklós: Az európai hadügy fejlődése a XIX-XX. században. Előadás. 143. kép

13 Ölvedi (1969) i. m. 63.

14 Ölvedi (1969) i. m. 63-64. 
A modern áttörő hadművelet - a szerző szerint - az alábbi módon kell hogy felépüljön:

- a háború kezdeti szakaszában az elővédegységek megkezdik az ütközetet, az átkaroló manőver lehetősége megszűnik, és megindul a hadműveleti áttöréssel kapcsolatos tevékenység;

- a gépesített magasabbegységekből álló elővédet - miután biztosította a főerők szétbontakozását - a szárnyak irányában kivonják, ezt követően a hadműveleti felépítés mélységébe kerül át;

- az elővéd helyébe érkező összfegyvernemi hadsereg(ek) összefüggő arcvonalat hoznak létre, a jelentős számú harckocsival és tüzérséggel megerősített összfegyvernemi magasabbegységek alkotják a rohamlépcsőt, amelynek harcait a légierőnek is támogatnia szükséges;

- mögöttük a korábban elővédként küzdő, nagyszámú, gyorsan mozgó egységből (amelyek az első lépcsőt alkották és szárnyirányban kitértek) megalakul a sikerkifejlesztö lépcső. ${ }^{15}$

A fent ismertetett tagozódás és manőverek garantálhatják az áttörés mélységi sikerét, a hadművelet célját, hogy egyidejüleg szétverje és felgöngyölítse a védelem teljes hadműveleti mélységét, ugyanis a rohamlépcső harcászati sikere következtében az első védelmi öv megroggyan, az ellenséges arcvonalon rés keletkezik, amelyet a sikerkifejlesztő lépcsőnek ki kell használnia. A sikerkifejlesztő lépcsőt megelőzi a légierő, amely haderőnem az áttörési szakasztól nagyobb távolságra lezárja az ellenséges tartalékok elöremozgásának a lehetőségét. ${ }^{16}$

A mély hadművelet végrehajtása során a hadmüveleti manőverezés két típusa (összpontosított csapásmérés és megkerülő csapás) összekapcsolódik, a rohamlépcső széles arcvonalon (frontálisan) fejti ki a tevékenységét, ezzel szemben a sikerkifejlesztő lépcső központosított csapást mér a védelem mélységében. ${ }^{17}$

Isszerszon tábornok müvében a mélységi hadmüveleteket ütközetek sorozataként írta körül, ebböl pedig levonta azt a következtetést, hogy a jövő konfliktusaiban a hadműveleti vezetés mindenekelőtt szervezési „müvészetként” határozható meg, ahol és amikor a vezetésnek elöre meg kell határoznia a hadművelet megszervezésének és vezetésének technikáját. ${ }^{18}$

\section{Felhasznált irodalom}

A harckocsi csapatok fejlödése. G-portál, 2007. Elérhető: http://szantomihaly.gportal. hu/gindex.php?pg=16866170\&nid=2862485 (A letöltés dátuma: 2019. 01. 19.) Carl von Clausewitz. Wikipédia. Elérhető: https://hu.wikipedia.org/wiki/Carl_von_ Clausewitz (A letöltés dátuma: 2021. 01. 20.) 
Holecz József: A Geraszimov-doktrína - Egy másik megvilágításban. Felderítő Szemle, 16. (2017), 3-4. 5-28. Elérhető: www.knbsz.gov.hu/hu/letoltes/fsz/2017-3-4.pdf (A letöltés dátuma: 2019. 01. 19.)

M. Szabó Miklós: Az európai hadügy fejlődése a XIX-XX. században. Előadás.

Ölvedi Ignác (szerk.): Szemelvények a szovjet katonai teoretikusok és katonai írók műveiből 1917-1940. Budapest, Zrínyi Miklós Katonai Akadémia Hadművészet Története Tanszék, 1969.

Resperger István: A gépesített hadviselés elmélete és megvalósítása, a Blitzkrieg. AETAS, 22. (2007), 4. 